\title{
THE BACKGROUND AND RESEARCH POTENTIAL OF THE FIRST SELKUP BOOKS BY N. P. GRIGOROVSKIJ
}

\author{
Nadezhda Fedotova \\ Kemerovo
}

\begin{abstract}
This article aims to explain why the dialectal identification of the Selkup texts compiled by Nikolaj Grigorovskij in the 19th century is still open. It also provides preliminary results on the isoglosses within the Southern dialectal group and strategies on how to address this problem. In order to advance the research, the first Selkup books of the 19th century (1879) have been converted into a digital annotated corpus of texts. Their analysis has revealed language features which, on the one hand, are accurately verified by Selkup material of the 20th century (on the example of the verb conjugation and the noun declension paradigms and the main Selkup isoglosses identified by Helimski. On the other hand, it has shown that the dialectal phenomena are insufficiently described. The article also gives the combined variant of Grigorovskij's biography existing as fragments in different sources.
\end{abstract}

Keywords: South Selkup dialects, Grigorovskij's biography, dialectal identification, noun declension, verb conjugation, isoglosses

DOI: https://doi.org/10.12697/jeful.2020.11.2.07

\section{Introduction}

The Selkup language is at present the only living representative of the South Samoyed group of the Uralic language family. The largest Selkup dialectal group is the northern one. Its speakers live in the northern part of the West Siberian Plain, Russia, on the rivers Taz, Turukhan, Baikha, Yeloguy. Between 1996-2002 the Department of the North and Siberia (the Ethnology and Antropology Institute of the Russian Academy of Sciences, Moscow) completed an investigation of the Selkup settlements in the Yamalo-Nenets Autonomous Okrug and in Krasnoyarsk Krai, which showed that there are no more than 600 native speakers of the North Selkup dialects left. According to the census of 2010, the total Selkup population was 3649 people (Vserossiyskaya perepis' 2010). Year by year the amount of the native speakers reduces in number. 
The native speakers of the South and Central dialects mostly live in the territory of Tomsk Region, in the South of the West Siberian Plain, Russia. Linguists from Tomsk State University (the Laboratory of Linguistic Anthropology) state that today there are no more than 5-6 native speakers in all the Central and South Selkup dialects left who can fluently speak Selkup. The present article focuses on the research of the South Selkup dialects. According to the most optimistic prognosis, it is estimated that today the number of speakers of South Selkup dialects is no more than 2-3 people.

In spite of the dramatic rates of the Selkup language extinction, the Southern dialects still remain the least described of all the Selkup dialects. Besides, there is no generally recognized classification of the Southern dialects so far. Fig. 1 shows the approximate border of residence of the South Selkups which means that the question of the southern border still remains open.

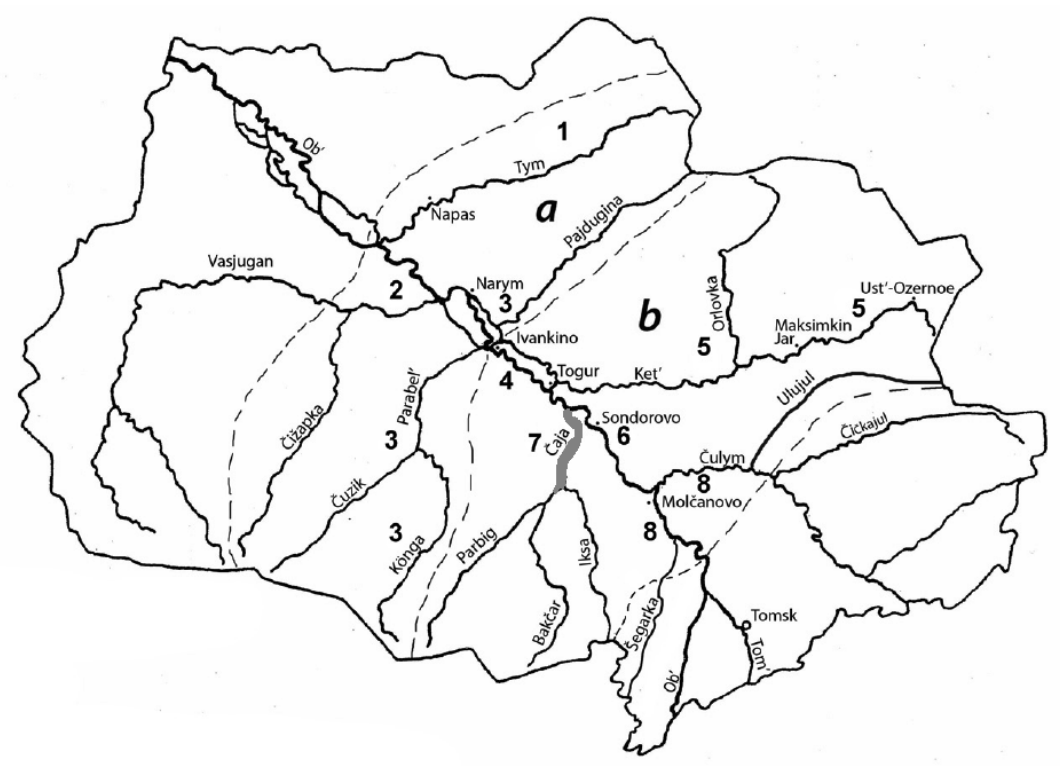

Figure 1. South and Central Selkups of the Tomsk region and their dialects. a) Central dialects: 1 Tym, 2 Vasyugan, 3 Narym; b) Southern dialects: 4 Middle-Ob, 5 Ket, 6 Upper-Ob (Sondorovo), 7 Chaya, 8 Chulym (Tučkova 2014: 8). 
Ethnographers argue that South Selkup territories extended up to the river mouth of Shegarka (Tučkova 2014: 8). Consequently, the region located to the South of the Ket' river still remains insufficiently described (including the texts recorded by Grigorovskij), and the Southern dialectal classification still remains unfinished. In addition, according to the latest research by Pozdeeva, it is fair to classify the Middle-Ob dialect as a transitional one between the Central and South Selkup dialects (Pozdeeva 2013). The Morphology by Bekker et al. (1995: 94-101) offers a generalized paradigm of noun declension for the Central and South Selkup dialects (see Table 2 below). In connection with this, the author of the article attempts to point out the main isoglosses which can help to make a clearer distinction between the South Selkup dialects within the South Selkup dialectal group, as this distinction does not yet exist.

The first books in Selkup had religious content and were translated by Grigorovskij into one of the South Selkup dialects in the 19th century. They were published in 1879 in Kazan. They consist of four works: 'The Sacred History in Ostyak-Samoyed' (Grigorovskij 1879a), 'Interpretation of the Holy Church Holidays' (Grigorovskij 1879b), 'A spelling book for the Syussogoy people' (Grigorovskij 1879c), 'Prayers and a tacit prayer to God' (Grigorovskij 1879d). These books represent the first attempt at the creation of Selkup literacy. Haidú (1973), Helimski (1983), and Katz (1988) introduced the South Selkup material published Grigorovskij into scientific discourse. However, Grigorovskij's books have remained outside social life so far: they were not used in schools to teach Selkup as they have been widely considered as inaccurate and containing mistakes.

The article consists of an introduction (1.), a section on the background of Grigorovskij's work and his biography (2.), a section on the history of research on Grigorovskij's books (3.), a section on the inflection of verbs and nouns as in Grigorovskij's texts compared with paradigms elicited from contemporary South and Central Selkup in the second half of the 20th century (4.), and a section in which phonological features of the data are discussed against the background of the South Selkup dialect isoglosses (Xelimskij 2004) (5.). Section 6 offers conclusions. 


\section{Biographical information on Nikolaj Grigorovskij}

The first Selkup books were written by Nikolaj Petrovič Grigorovskij in the middle of the 1870s in the settlement of Jurty Kostenkiny (Tomsk Governorate, Chaya Volost, lower course of the river Chaya, running into the river Ob) (Rassamaxin 2000). Grigorovskij worked there from 1873 as a tutor in a well-to-do Selkup family whose surname still remains unknown. At that time, because the Selkups had no written language, the tutor started preparing a spelling book for his students and became the founder of the South Selkup literacy (Arxim. Meletij 1876: 29). It is reported that the local Selkups would come to listen to Grigorovskij's translations when he would read his texts out loud and invariably the Selkups asked for further translations (Arxim. Meletij 1876: 30). As a result, other books followed and were published together with the Azbuka in 1879 in Kazan. The language of the books clearly belongs to one of the South Selkup dialects (Xelimskij and Grigorovskij 2007: 3).

There is no reliable information concerning Grigorovskij's education level. The available information we can rely upon is an excerpt from a letter, where Grigorovskij speaks of himself as a man who "can earn his daily bread only by writing" (Arxim. Meletij 1876: 29). Moreover, the education level allowed him to begin a career as a government official. Up to 1866 Grigorovskij held the post of an assistant forest warden (mladšij lesničij) in Udmurtiya, Russia, whose responsibility was to protect the local forest from woodcutting (Rassamaxin 2000: 267). But he allowed peasants to cut the wood for personal use. As a result, in 1866 Grigorovskij was exiled in accordance with the administrative order to Siberia (to the settlement of Novoe, Narym district, Tomsk Governorate, Russia - today Novoil'inka village, Kolpaševo district, Tomsk region). Thus, he lost the opportunity of career development as a state official (Rassamaxin 2000: 267). It should not be forgotten that later Grigorovskij was invited to work for the West Siberian Department of the Imperial Geographic Society with the rank of a collegiate secretary (kolležskij sekretar'). This rank was usually given to students after graduation from a higher education institution. We can assume that Grigorovskij's education was quite good, and most probably it was a higher education in the humanities. The name of the university, however, remains unknown. 
Grigorovskij made his translations with the help of his students' father in Jurty Kostenkiny, and other family members as well. His translation activity involved the following stages: first, Grigorovskij read the Russian texts aloud sentence by sentence, which were translated afterwards by the Selkups and written down by him (Arxim. Meletij 1876: 29). Second, he checked the translations by asking the meaning of every word from the Selkups. Moreover, he asked Russian speaking Selkups to interpret the meaning of the Selkup texts back to Russian, to make sure that they fully comprehended his translations (Arxim. Meletij 1876: 29-30). Therefore, it is evident that the material was thoroughly examined both by the speakers of the Selkup and by Grigorovskij himself. At the end of this work Grigorovskij received certifications from four heads of different Selkup communities to confirm that the translations were fully comprehensible for residents of Narym Krai (Csepregi 1976: 221). Most probably these were representatives of the Southern dialects. Their names are unknown.

Speaking about the personality of Grigorovskij, it is worth mentioning that he enjoyed an excellent reputation among the Selkups of Narym Krai. Records in the parish registers of St. Prophet Elijah Church in Novoe, where Grigorovskij lived before and after his work in Jurty Kostenkiny, show that he became a godfather to twenty-six newborn babies between 1876 and 1883 (Rassamaxin 2000: 269-270). Church records in the settlement of Togur indicate that the residents of this village also wanted to him as a godparent for their children (Rassamaxin 2000: 269-270). In spite of the fact that in 1877 he was pardoned and exempted from all the consequences of the exile, the translator decided to stay in Narym Krai (Novoe) and continue his work on the documentation of the local indigenous language and their culture (Rassamaxin 2000: 269).

The members of St. Guriy Brotherhood (Kazan, Russia) learnt about Grigorovskij's activity and offered their collaboration in publishing the translations, as they also made translations of the Bible into other Uralic and Altaic languages. In 1876 Grigorovskij presented the Selkup spelling book and other translations to the Orthodox Missionary Society in Kazan, attaching certifications from four heads of different Selkup communities that the translations were fully comprehensible for residents of Narym Krai (Csepregi 1976: 221-222). After the publication of his translations Grigorovskij switched to working for the West 
Siberian Department of the Imperial Geographic Society with the rank of a collegiate secretary and collected ethnographic material for them (Rassamaxin 2000: 274).

Grigorovskij's biographical information indicates that he had an education enough to work with the rank of a collegiate secretary in the West Siberian Department of the Imperial Geographic Society. It is noteworthy that he gained great credibility among the Selkups who actively took part in his translations.

\section{The history of the research of the first Selkup books}

The Selkup books by Grigorovskij were forgotten after the Soviet government established itself in 1917, right after the overthrow of the Tsarist regime. Most probably it happened due to ongoing religious persecution under the Soviet regime at that time.

In the first half of the 20th century the first Selkup books are mentioned only once. There is one remark in "The Languages and Script of the Indigenous Peoples of the North" by Gennadij Prokof'ev, researcher of the Northern dialects of Selkup (Prokof'ev 1937: 95-96), which states that it was impossible to use Grigorovskij's Azbuka to teach Northern Selkups due to huge dialectal differences leading to lack of understanding of the texts (Prokof'ev 1937: 95-96).

Grigorovskij's writings were forgotten for several decades, until Peter Hajdú renewed interest in these books in the early 1970s when he published a faksimile reprint of the Azbuka (Hajdú 1973), and in 19731974, on the initiative of her academic adviser Hajdú, Márta Csepregi went on an internship to Leningrad to work with the archives and make the first attempt to write an article on Grigorovskij's biography (Csepregi 1976). ${ }^{1}$ At the same time researchers in Russia considered his books as material unintelligible for Selkups. A short remark by Angelina Kuz'mina (1974: 177) illustrates this statement: "The Selkups refused to accept his books as their native". Most probably researchers realized that studying religious texts under the Soviet regime was impossible

I am grateful to Márta Csepregi who kindly shared her article and comments on it with me. 
and, what was crucial, was that these texts were incomprehensible to the North Selkups who are still a large population group.

In the 1980s the Russian and German linguists Eugene Helimski and Hartmut Katz continued the study. Helimski wrote a book called "The Language of the First Selkup Books" (Helimski 1983), and Katz published an analysis of the Azbuka, which was provided with transcriptions, translations into German and the author's comments (Katz 1988). Ago Künnap (1979) mentioned the Azbuka in his analysis of Russian loan words in different Selkup and Kamas materials. These researchers discuss grammatical and phonetical issues of the Selkup language documented in the books. Among other things Helimski raises the question of the usage of Genitive and Accusative case markers in Grigorovskij's texts, as they are different from the common practice in other Selkup dialects: "it is not easy to understand why Grigorovskij distorted the Genitive and Accusative forms so gravely while he had no difficulties with other, much less frequent and obvious, cases (translative, destinative, etc.)" (Helimski 1983: 33). This uncommon usage might be the characteristic feature of this insufficiently described Southern dialect and should be thoroughly studied. The description of this problem should be undertaken in a separate article.

One must also mention Grigorovskij's lexical work. In the preface to a South Selkup dictionary which he had compiled and which was discovered only in 1985 and published by Helimski in 2007, Helimski wrote: "The volume, quality and value of the lexicographic material is beyond all expectations. Furthermore, Grigorovskij's dictionary can still be regarded as a translation dictionary due to its practical importance: no Russian-Selkup dictionaries appeared in the last 130 years comparable in volume to this one (Xelimskij and Grigorovskij 2007: 3).

To sum up, Grigorovskij's books are a unique corpus of an extinct, but insufficiently explored and described Southern dialect. The Selkup syntax in Grigorovskij's books had undergone changes due to assimilation to Russian. Also a significant quantity of Russian borrowings demonstrates the level of assimilation with Russian, which was common to the dialect of lower Chaya residents at the end of the 19th century. Therefore, Grigorovskij documented the language, which was spoken and understood by the Selkups in this region. 


\section{Comparison of the first Selkup books of the 19th century with the material of the second half of the 20th century - accuracy and reliability}

\subsection{Paradigms of verb conjugation}

Firstly, it should be mentioned that in the "Azbuka", "The Sacred History in Ostyak-Samoyed Language", and "The Interpretation of the Holy Church Holidays" there are paradigms of verb conjugation and noun declension similar to the material of the second half of the 20th century (Bekker et al. 1995, Kuznecova 1995). Speaking about the paradigms we imply the ones elicited by the author of this article from the digital annotated corpus of Grigorovskij's books. ${ }^{2}$ Today the most complete description of the South Selkup verb is the book by Nadežda Kuznecova (1995). It offers several paradigms from the Central (Tym and Narym) and the Southern (Middle-Ob and Ket) dialects. It also gives separate examples from other dialects. The paradigms are mostly generalized, and the grammar does not provide us with the full description of each of the dialects. The paradigms by Grigorovskij show a large degree of similarity with the South Selkup dialects. However, they have a number of distinctions, which can be seen below in Table 1 .

Table 1.1. Person and number suffixes of the non-imperative paradigm in the Ket dialect and the dialect of the first Selkup books

\begin{tabular}{|c|c|c|c|c|}
\hline \multirow[b]{2}{*}{ Conjugation } & \multicolumn{2}{|c|}{ Ket (Kuznecova 1995: 161) } & \multicolumn{2}{|c|}{ Grigorovskij } \\
\hline & Subjective & Objective & Subjective & Objective \\
\hline $1 \mathrm{SG}$ & $-(a) \eta$ & -(a)m, -(a)ß & -анг (-ay) & -ay (-au), -oy (-ou) \\
\hline $2 \mathrm{SG}$ & -(a)ndi, -(a)ddi & $-(a) 1$ & -ант (-ant) & -аль $\left(-\mathrm{a}{ }^{\mathrm{j}}\right)$ \\
\hline $3 \mathrm{SG}$ & -n; -an; -a; -Ø & $-\mathrm{t},-\mathrm{ti}$ & -ан (-an) & -ит (-it) \\
\hline $1 \mathrm{DU}$ & \multicolumn{2}{|l|}{-0} & \multicolumn{2}{|c|}{-} \\
\hline $2 \mathrm{DU}$ & \multicolumn{2}{|c|}{-(a)li } & \multicolumn{2}{|c|}{-(е)ли (-elji) } \\
\hline $3 \mathrm{DU}$ & \multicolumn{2}{|c|}{$-(a) t i$} & \multicolumn{2}{|c|}{$-(\mathrm{a}) \Gamma(-\mathrm{ag})$} \\
\hline $1 \mathrm{PL}$ & \multicolumn{2}{|c|}{$-o t$} & \multicolumn{2}{|c|}{-ут (-ut) } \\
\hline $2 \mathrm{PL}$ & \multicolumn{2}{|c|}{-(a)lit } & \multicolumn{2}{|c|}{-(а)лт (-(a)lt) } \\
\hline $3 \mathrm{PL}$ & (?-at) & -atit, -atti & \multicolumn{2}{|c|}{-ат (-at) } \\
\hline
\end{tabular}

2 The corpus was created under the project "The Language and Cultural Diversity of South Siberia in Synchrony and Diachrony: Mutual Influence of Languages and Cultures” (грант Правительства России № 14.Y26.31.0014). 
Table 1.2. Person and number suffixes of the non-imperative paradigm in the Middle-Ob dialect and the dialect of the first Selkup books

\begin{tabular}{|c|c|c|c|c|}
\hline \multirow[b]{2}{*}{ Conjugation } & \multicolumn{2}{|c|}{$\begin{array}{c}\text { Middle-Ob (Kuznecova } \\
\text { 1995: 161) }\end{array}$} & \multicolumn{2}{|c|}{ Grigorovskij } \\
\hline & Subjective & Objective & Subjective & Objective \\
\hline $1 \mathrm{SG}$ & -(a)k, -(a)y & -(a)p, -(a)m & -анг (-ay) & -ay (-au), -oy (-ou) \\
\hline $2 \mathrm{sG}$ & -(a)nd & $-(\mathrm{a}) 1$ & -ант (-ant) & -аль $\left.(-\mathrm{al})^{\mathrm{j}}\right)$ \\
\hline $3 \mathrm{SG}$ & $-a ;-\varnothing ;(-n<-n)$ & $-t$ & -ан (-an) & -ит (-it) \\
\hline $1 \mathrm{DU}$ & \multicolumn{2}{|l|}{$-(a) i$} & \multicolumn{2}{|c|}{-} \\
\hline $2 \mathrm{DU}$ & \multicolumn{2}{|c|}{$-(a) l i$} & \multicolumn{2}{|c|}{-(е)ли (-elji) } \\
\hline $3 \mathrm{DU}$ & \multicolumn{2}{|c|}{-(a)gi, (-at) } & \multicolumn{2}{|c|}{$-(\mathrm{a}) \Gamma(-\mathrm{ag})$} \\
\hline $1 \mathrm{PL}$ & \multicolumn{2}{|c|}{-(a)ut } & \multicolumn{2}{|c|}{ ут (-ut) } \\
\hline $2 \mathrm{PL}$ & \multicolumn{2}{|c|}{$-(a) l t$} & \multicolumn{2}{|c|}{-(a)лт (-(a)lt) } \\
\hline $3 \mathrm{PL}$ & $(?-a t)$ & $\begin{array}{c}\text {-adit, } \\
\text {-at }(?<- \text {-atti) }\end{array}$ & & ат (-at) \\
\hline
\end{tabular}

Table 1.3. Person and number suffixes of the non-imperative paradigm in the Narym dialect and the dialect of the first Selkup books

\begin{tabular}{|c|c|c|c|c|}
\hline \multirow[b]{2}{*}{ Conjugation } & \multicolumn{2}{|c|}{$\begin{array}{c}\text { Narym dialect (Pusztay and } \\
\text { Kuper 1993: 69) }\end{array}$} & \multicolumn{2}{|c|}{ Grigorovskij } \\
\hline & Subjective & Objective & Subjective & Objective \\
\hline $1 \mathrm{SG}$ & $-\mathrm{K}(\mathrm{k})$ & $-(a) \Pi((a) p)$ & -анг (-aү) & -ay (-au), -oy (-ou) \\
\hline $2 \mathrm{sG}$ & -(a)нд ((a)nd) & -(a)л ((a)l) & -ант (-ant) & -аль $\left(-\mathrm{al}^{\mathrm{j}}\right)$ \\
\hline $3 \mathrm{SG}$ & $-a,-\varnothing$ & -(ы)д ((i)d) & -ан (-an) & -ит (-it) \\
\hline 1DU & \multicolumn{2}{|c|}{-(a)й $((a) \underline{i})$} & \multicolumn{2}{|c|}{-} \\
\hline $2 \mathrm{DU}$ & \multicolumn{2}{|c|}{-(a)ли ((a) $1 \mathrm{ji})$} & \multicolumn{2}{|c|}{-(e)ли (-elji) } \\
\hline $3 \mathrm{DU}$ & \multicolumn{2}{|c|}{$-(\mathrm{a}) \Gamma((\mathrm{a}) \mathrm{g})$} & \multicolumn{2}{|c|}{$-(\mathrm{a}) \Gamma(-\mathrm{ag})$} \\
\hline $1 \mathrm{PL}$ & \multicolumn{2}{|c|}{-ут (u-t) } & \multicolumn{2}{|c|}{-ут (-ut) } \\
\hline $2 \mathrm{PL}$ & \multicolumn{2}{|c|}{-(a)лт ((a)l-t) } & \multicolumn{2}{|c|}{-(a)лт (-(a)lt) } \\
\hline $3 \mathrm{PL}$ & \multicolumn{2}{|c|}{-(a)дәт ((a)də-t), (?-a-t) } & \multicolumn{2}{|c|}{-ат (-at) } \\
\hline
\end{tabular}

The paradigms of verb conjunction in the first Selkup books show similarity to the paradigms from the Ket and Middle-Ob dialects, which indicates the affiliation to some Southern dialect and, at the same time, the quality and consistency of the 19th century material: 
1) availability of singular, dual and plural number;

2) the distribution into subjective and objective conjugation;

3) regular phonetic matchings in suffixes.

The first Selkup books also demonstrate the distinctions, which differentiate the South Selkup dialect from the Central and from the Northern ones. These differences can be considered as isoglosses drawing a border between the Southern dialects and the Central and Northern ones:

4) the suffix - an indicating 3sG.SuB;

5) vocalization of consonants in 1sG.OB: $m / p$ (Central, North) $\sim u / \beta$ (South).

The following differences can be also pointed out in the endings of the Ket, Middle-Ob, Narym dialects and the dialect of Grigorovskij's texts:

6) Regular -ant in 2sG.SUB in Grigorovskij's texts, which is different from other dialects in Table 1.

7) Regular - $a g$ in 3DU in Grigorovskij's texts, which is different from another Southern dialect - the Ket dialect, being at the same time closer to the Middle-Ob and Narym dialects.

Nevertheless, it can be concluded that Grigorovskij's texts, recorded at the lower course of the river Chaya, belong to one of the Southern dialects. They contain a number of consistent distinctions, which may indicate the attribution to an insufficiently described Southern dialect (Chaya, Upper-Ob, Lower Ket or another).

\subsection{The declension of nouns in the first Selkup books}

Today the most complete description of the grammar categories of nouns is the "Morphology of Selkup (Southern dialects) (Bekker et al. 1995). Below in Tables 2.1 and 2.2 there are the suffixes of the impersonal declension paradigms in comparison with the paradigms from Grigorovskij's texts. There is also a column containing the paradigm from the Chulym dialect taken from Castrén's 19th century material (Castrén 1854: 149), as there are almost no other sources of paradigms for this dialect. 


\begin{tabular}{|c|c|c|c|c|c|c|c|}
\hline 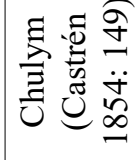 & i & 訔 & & $\varphi_{p}$ & & & \\
\hline 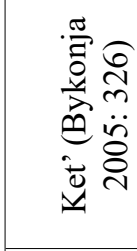 & 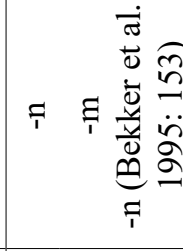 & & & 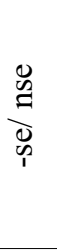 & 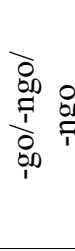 & & 奠 \\
\hline 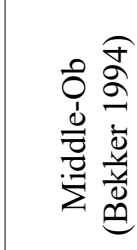 & 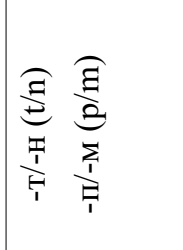 & 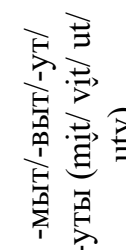 & & 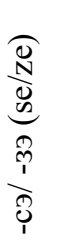 & 宊 & & 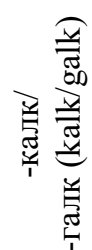 \\
\hline 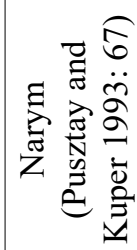 & i & 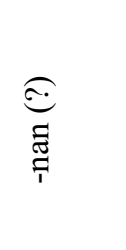 & 蟋 & $\%$ & $\therefore$ & $\therefore$ & 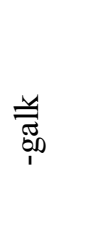 \\
\hline & 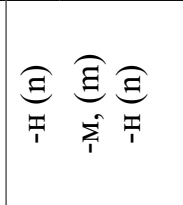 & $\begin{array}{l}\text { 害 } \\
\text { 萦 }\end{array}$ & $\begin{array}{l}\text { o } \\
\text { 吾 } \\
\text { 号 }\end{array}$ & 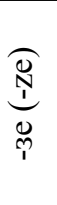 & 亭 & 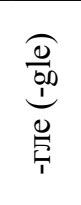 & 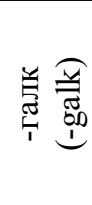 \\
\hline 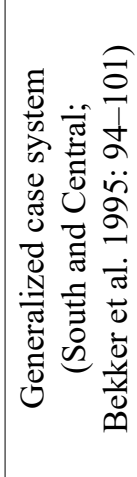 & 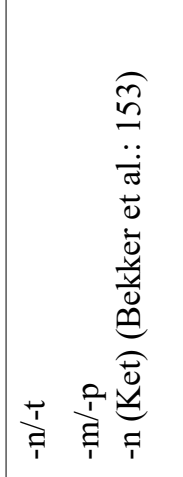 & 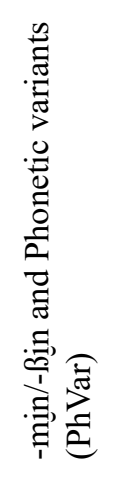 & 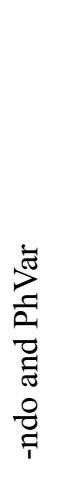 & 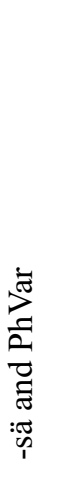 & 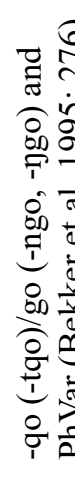 & 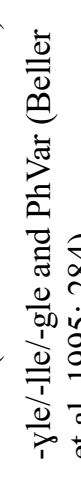 & \\
\hline & 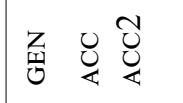 & $\overrightarrow{\stackrel{\mathscr{a}}{a}}$ & $\vec{q}$ & & & & $\approx$ \\
\hline
\end{tabular}


178 Nadezhda Fedotova

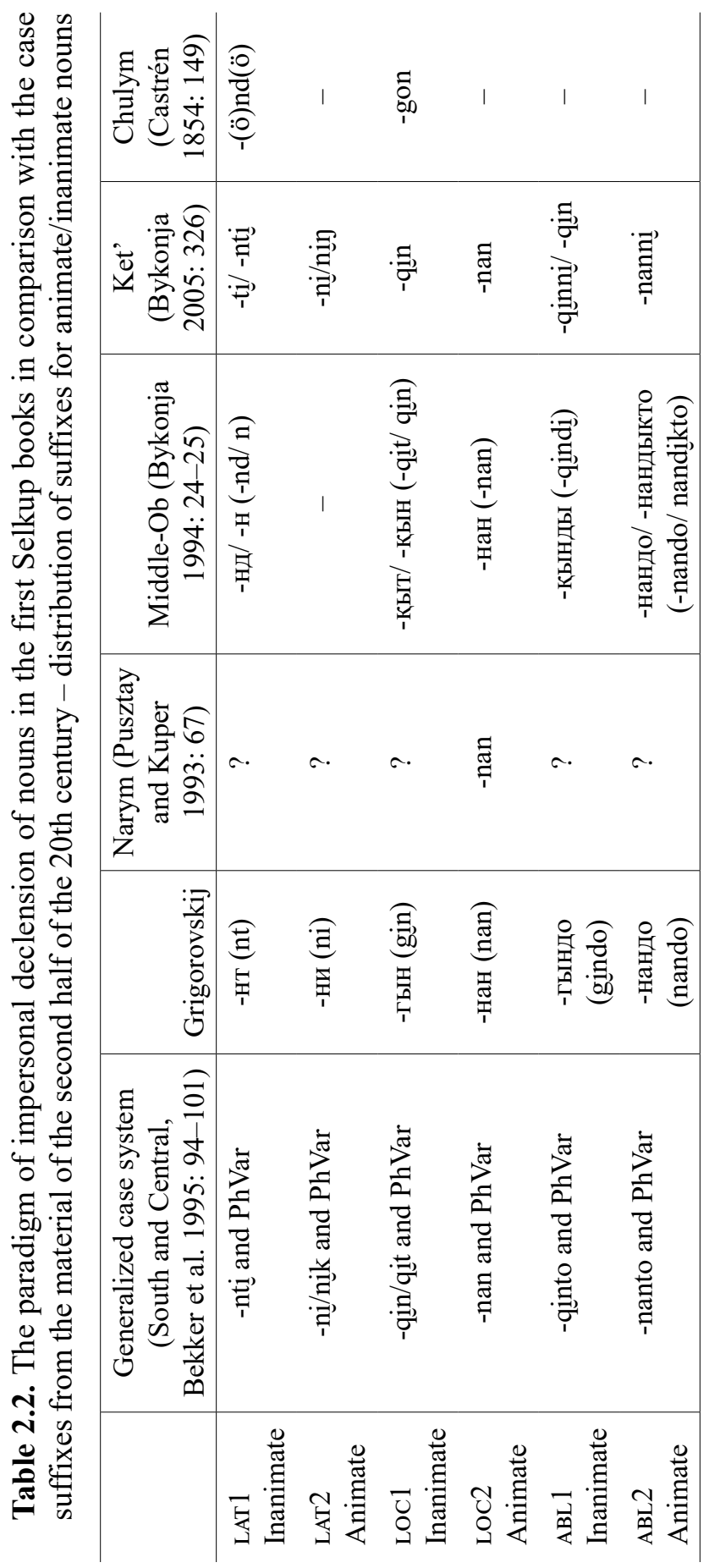


It is important to emphasize that the case system and case markers elicited from Grigorovskij's texts demonstrate accuracy and consistency: 1) All the cases can also be found in other Selkup dialects and have regular phonetic matchings.

2) Some cases have 2 types of suffixes which are used to mark animate and inanimate objects (See Table 2.2 Lative, Locative, AblativeLocative). The same distribution can be found in the material of the 20th century.

3) Occurrence of n-Accusative: in the middle of the 20th century it used to be thought that the n-Accusative was a misspelling in field materials. However, later researchers came to the conclusion that the n-Accusative does exist in the Southern dialects of Selkup (except Middle-Ob dialect of the Shyoshkup /Shyoshkums) and most often is used to mark the objects which are "not-mine", "not-close" (Bekker et al. 1995: 155). This theory requires further verification.

To sum up, the case system elicited from the first Selkup books is surprisingly accurate and consistent when it is compared to the material of the second half of the 20th century. The history of study of the first Selkup books, the biography of their author, and the paradigms elicited by the author of this article prove the consistency and quality of the first Selkup books.

Grigorovskij's texts recorded in the 19th century also indicate that the level of Selkup-Russian assimilation was very high among the residents of lower Chaya region. Their Selkup abounds with Russian loanwords built into the language with the help of different derivational and inflectional Selkup affixes: асъ заботимгу - не заботиться (Xelimskij 2007: 76), асъ справедливангъ - не справледливо (Xelimskij 2007: 77). And Grigorovskij fixed the language with this level of Russian interference into Selkup, which was common to the Selkups living in the lower Chaya region in the 1870s.

\section{The problem of dialect identification of the first Selkup books}

Regrettably, the distinctive features of the noun and verb Selkup paradigms for each of the Southern Selkup dialects have not been strictly identified, except for Middle Ob and Ket dialect (See Tables 2.1, 
2.2 above). Moreover, it is important to distinguish Lower, Middle and Upper Ket vernaculars. The paradigm of the Chulym dialect, recorded by M.A. Castrén and given above in Table 2.1 and 2.2, is based on two nouns and does not show a full case system (Castrén 1854: 149). All the above highlights the lacuna which we have in the sphere of the Southern Selkup dialects.

There is no distinct description of boundaries of each of the Southern Selkup dialects. And there are no clear isoglosses inside the Southern Selkup dialectal group. In view of this the dialectal identification of the texts recorded by Grigorovskij can be stated only approximately, and the description of each of the Southern Selkup dialects is a goal for further investigations.

According to the following isoglosses elaborated by Helimski (Xelimskij 2004), Grigorovskij's texts can be definitely attributed to the South Selkup dialectal group. The author of the article introduces below the new materials from the digital corpus of the Narym dialect (Korobejnikova 2009) and regular Grigorovskij variants as well to compare the Grigorovskij's texts dialect to other available dialects:

1) Northern and Central $\check{s} \sim$ Southern $s$ (Xelimskij 2004: 71)

Grigor. $\boldsymbol{a c b}$ - Taz. $a \check{s} \check{s} a$ (Xelimskij 2007) - Nar. $a$ (Korobejnikova 2009) - Chaya as (Sk Wb 229, Alatalo 2004: 38) - Bajdona OO as̀ (ibid.) - Ket. KeM as̀s, $\mathrm{KeO}$ as̀są (ibid.) 'not' (negative particle)

Grigor. cыıb - Taz. šitti (Xelimskij 2007) - Nar. $\int \varepsilon d$ (Korobejnikova 2009) - Chaya sәิd' 'два' (SkWb 2521, Alatalo 2004: 357) - Ket. KeUM šitto, KUS šitta, KeM šitta, KM šitto, KeO sitto (ibid.) 'two'. In this case the Ket dialect stands out with its $\check{s}$.

Grigor. $c e$ - Taz. $\check{s} \bar{e}$ (Xelimskij 2007) - Nar. šc (Korobejnikova 2009) - Chaya. sie (SkWb 2420, Alatalo 2004: 346) - Bajdona OO șé, $s^{i} \bar{e}$; OO1 şie (ibid.) - Ket. KeUM șe, KeM $s \bar{\varepsilon}, \mathrm{KM} s \bar{e}, \mathrm{KeO} s \bar{\varepsilon}$ (ibid.) Sondorovo OOS śē (ibid.) - Taizakovo OOT sie 'tongue'

Grigor. cю - Taz. š $\bar{u}$ (Xelimskij 2007) - Nar. šü (Korobejnikova 2009) - Chaya sü (SkWb 2423, Alatalo 2004: 346) - Bajdona OO

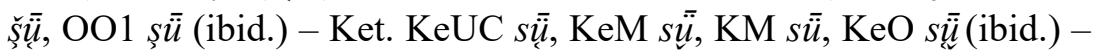
Sondorovo OOS śü (ibid.) - Taizakovo OOT sü (ibid.) 'snake'

Grigor. сак (Xelimskij and Grigorovskij 2007) - Taz. šäq (Xelimskij

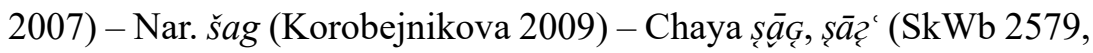




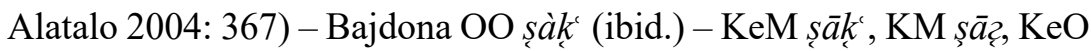
$s \bar{a} \chi_{\iota}, s \bar{a}_{2}$ ' (ibid.) 'salt'

Grigor. cez (Xelimskij and Grigorovskij 2007) - Taz. šéki (Xelimskij 2007) - Nar. šcg (Korobejnikova 2009) - Chaya şè ègr (SkWb 2619, Alatalo 2004: 371) - Bajdona OO şiè (ibid.) - KeM sēya, KeO sęckai (ibid.) - Sondorovo OSA šę̧y (ibid.) 'thread'

2) Southern $s \sim$ Central $\chi$ (Xelimskij 2004: 72)

Can be observed, in particular, in the instrumental case (See Table 2.1), and in the following lexemes:

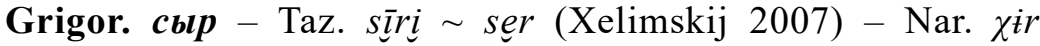
(Korobejnikova 2009) - Chaya sèr (SkWb 2633, Alatalo 2004: 373) -

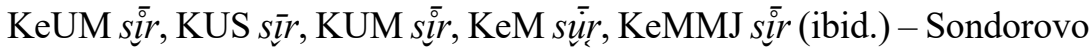
OOS sīr, OSA sīr (ibid.) 'cow'

Grigor. сыбынди́ - Taz. sipinin'ca (BT) sịwin'ca (Xelimskij 2007) -

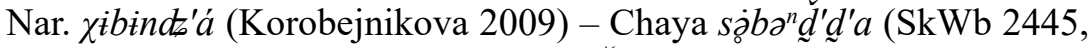
Alatalo 2004: 349) - Bajdona OO såbåd̆d'a (ibid.) - KeM sạb $n d^{2} a, \mathrm{KM}$ si. Bind'a (ibid.) 'pig'

Grigor. cэp - Taz. siri (Xelimskij 2007) - Nar. $\chi \dot{i r}$ (Korobejnikova

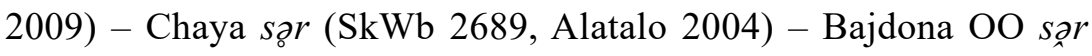
(ibid.) - KeM sęrra, KM sirrra (ibid.) - Sondorovo OOS sąr (ibid.) 'snow'

Grigor. сельдчь - Taz. sēl'ci (Xelimskij 2007) - Nar. $\chi^{\prime} \varepsilon l^{\prime} d t^{\prime}$ (Korobejnikova 2009) - Chaya sièld's (SkWb 2741, Alatalo 2004) Bajdona OO şsièld' (ibid.) - KUS sēंld'ǔ sēld's, KUM seld'u, seld's, $\mathrm{KeM}$ sęld'u, KM sēeld'u, KeO sēll'u, KeOš sēld'u, sēld'i, sēld's (ibid.) Sondorovo OSA șèlld'i (ibid.) 'seven'

Grigor. со́мбла, со́мблак (Xelimskij and Grigorovskij 2007: 181) -

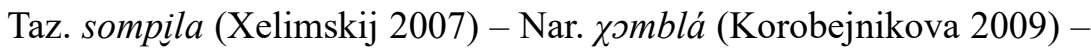
Chaya șomb tak (SkWb 2472, Alatalo 2004: 352) - Bajdona OO

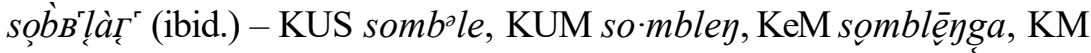

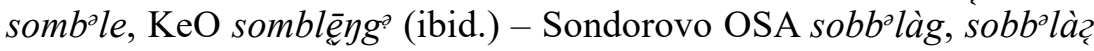
(ibid.) 'five'

Grigor. cóú - Taz. sōl' (Xelimskij 2007) - Nar. $\chi \supset l '$ (Korobejnikova 2009) - Chaya $s^{u} \overline{\partial i}$ (SkWb 2568, Alatalo 2004) - Bajdona OO sōi (ibid.) - KeM sọ̀i, KM sōin, KeO sōi $i \bar{\alpha}$ s̄i (ibid.) - Sondorovo OOS sōi $i$ (ibid.) 'throat' 


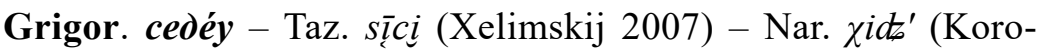
bejnikova 2009) - Chaya. sịd', șín' (SkWb 2555, Alatalo 2004: 363) -

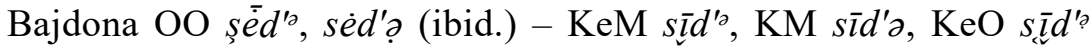
(ibid.) - Sondorovo OOS sid', OSA sid'i, si.d'i (ibid.) 'heart'

Grigor. cýpyм - Taz. sūrim (Xelimskij 2007) - Nar. ұúrup (Korobejnikova 2009) - Chaya sūrum (SkWb 2683, Alatalo 2004: 379) - KM sūrnm, $\mathrm{KeO}$ sūrām (ibid.) 'beast, animal'.

3) The alternation Southern $-m \sim$ Central $-p$ in auslaut position

A characteristic isogloss, which helps identify the Central and Southern dialects (Xelimskij 2004: 70). The border line lies on the territory where the śoškup/šsoškum live (Middle Ob, Kolpashevo), where free variation is possible (Pozdeeva 2013). The consonants $m \#$ (Southern)/ $p \#$ (Central) vary freely in the Accusative and in the suffix of 1sG.OB (see Table 1, Table 2 above). The regular Accusative suffix in Grigorovskij's texts is - $m$ (vs. $-p$ in the Central dialects). The given alternation can be observed in the auslaut position of nouns:

Grigor. Нoм $\sim \boldsymbol{H} \boldsymbol{y} \boldsymbol{M}$ - Taz. nom $_{2}(n \bar{u}-)(X e l i m s k i j ~ 2007)-$ Nar. $n>p$ (Korobejnikova 2009) - Chaya nọm (SkWb 1345, Alatalo 2004: 196) Bajdona OO nom (ibid.) - KeUM num, KeM nom, KM nom, $\mathrm{KeO}$ nom (ibid.) - Sondorovo OOS nom (ibid.) 'God'

Grigor. кум $\sim$ ком - Taz. qum 2 (Xelimskij 2007) - Nar. kup (Korobejnikova 2009) - Chaya k'um, k'úm (SkWb 1858, Alatalo 2004: 269) - Bajdona OO ḱum (ibid.) - KUM ķum, KeM kূum, KM kqum,

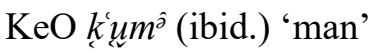

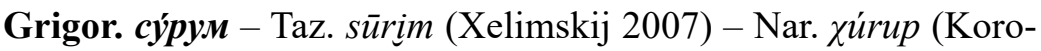
bejnikova 2009) - Chaya sūrum (SkWb 2683, Alatalo 2004: 379) - KM sūrnm, $\mathrm{KeO}$ sūrām (ibid.) 'beast, animal'

Grigor. ором - Taz. orim 3 or (Xelimskij 2007) - Nar. or (Korobejnikova 2009), N ora (SkWb 269, Alatalo 2004: 45) - Chaya or ${ }^{\hat{\imath}} m$ (ibid.) - Bajdona OO ōrâm (ibid.) - KeM ợ ${ }^{\hat{\imath}} m$, KM orəm, $\mathrm{KeO}$ orām (ibid.) 'strength'.

4) Southern $k$ - $\sim$ Central and Northern $\dot{t}$ - or $\dot{c}$ - in anlaut position (Xelimskij 2004: 72)

Grigor. кю́ нm - Taz. cuntị (Xelimskij 2007) - Nar. t6und (Korobejnikova 2009) - Chaya küd d (SkWb 1512, Alatalo 2004: 218) -

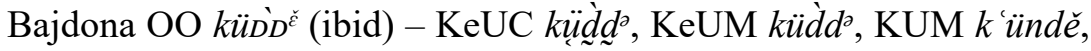


KeM kündə, KM kündə, KeO kündd (ibid.) - Sondorovo OOS küdd , OSA küddî (ibid.) 'horse'

Grigor. $\boldsymbol{\kappa ю ~ - ~ T a z . ~} c \ddot{u} \sim c \bar{u}$ (Xelimskij 2007) - Nar. t6o (Korobejnikova 2009) - Chaya $k \dot{u}$ (SkWb 1433, Alatalo 2004: 208) - Bajdona OO $k \bar{u}$ (ibid.) - KeM kü $, \mathrm{KM} k \bar{u}, \mathrm{KeO} k \bar{u}$ (ibid.) 'belt'

Grigor. кё̈зынг - Taz. cüša cüšani (Xelimskij 2007) - Nar. t6'udzəgú (Korobejnikova 2009) - Chaya kǚs- (SkWb 1581, Alatalo

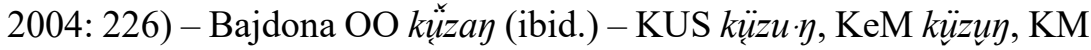

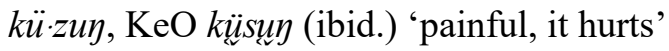

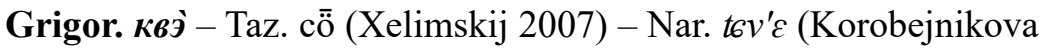
2009) - Chaya $k^{u} \ddot{o}$ (SkWb 1435, Alatalo 2004: 208) - Bajdona OO $k^{u ̈} \bar{O}$ (ibid.) - KeUM kvörg, KUS kü̈rga, KeM kuprq̣â, KM kuèrga, KeO kuprga, KeOL kud̀rg (+?SkWb 2256, Alatalo 2004: 327) 'pine'

Grigor. ке́um - Taz. CT чiнmbl (Kazakevič 2010: 161) - Nar. t ššzndr (SkWb 1513, Alatalo 2004: 219) - Chaya kadd do (ibid.) - Bajdona OO kạDDě (SkWb 1513, Alatalo 2004: 219) - KeM kö̆ñi, KeO kő̀ndi (ibid.) - Sondorovo OOS kiddde (ibid.) 'bow-string'.

The first Selkup books were recorded at the lower course of the Chaya river. The self-designation of Grigorovskij's informants s'usogom makes it impossible to identify the texts with the Central dialects (self-designation čumyl'kup) or the Middle Ob dialect (self-designation š́oškup/ššškum). Grigorovskij's texts demonstrate the following phenomena which occur only in the Southern dialects:

1) Vocalization of the consonant $m$, which can occur in the verb conjugation paradigms in 1sG.OB and in the possessive noun form of 1sG.POSs $-m$ (the Central and Northern) $\sim-\beta \sim-y$ (the Southern) (cf. Glushkov et al. 2004: 53).

2) Diphthongization of vowels. Sergej Gluškov (2001) is the first researcher who paid attention to the diphthongs as a distinctive feature of the Chaya dialect. The material of Jarmo Alatalo's "Sölkupisches Wörterbuch" (2004) supports this statement. The phenomenon deserves more attention and requires a deeper study to be undertaken.

In this regard it is important to take into consideration the work of the Novosibirsk scholars Kiseleva and Nikiforova (1969), who state that diphthongs also occur in the Ket dialect, namely in the Karelino 
vernacular. They refer to the materials by Angelina Kuzmina. However, the authors speak of their results as preliminary and do not provide any metadata (including surnames) of their informants. In connection with this, we cannot fully rely on the investigation by Kiseleva and Nikiforova, whereas we cannot also overlook the fact that diphthongization may be characteristic not only to the Selkup speakers living in the Chaya region, but also spread over the South Selkup territories as for instance the far South speakers of the settlements of Sondorovo, Taizakovo and others (cf. Glushkov et al. 2004, Filippova 2011) and to the north-east closer to the Ket' dialect speakers as well (Kiseleva and Nikiforova 1969). The following diphthongs are recorded in the texts by Grigorovskij:

1) bíчь 'word' (GH 1655, Xelimskij and Grigorovskij 2007: 220)

2) biopbl-, blp- 'to feast' (GH 1647, Xelimskij and Grigorovskij 2007: 220), юе́ренди 'drunk' (SkWb 276)

3) квьіаргу/ кво́аргу/ квэ́ргу/ кво́ргу 'to call' (GH 305 квыьор, SkWb 2250) (Xelimskij and Grigorovskij 2007: 104)

4) пúумбыгу 'запутаться' SkWb 595 (Xelimskij and Grigorovskij 2007: 162), cf. пюугу 'to tangle oneself' SkWb 595 (Xelimskij and Grigorovskij 2007: 171).

The above mentioned article by Gluškov (2001) is the only paper specially devoted to the description of the Chaya dialect. However, the criteria given in the article are still not enough to indentify any text as belonging (or not) to the Chaya dialect. Ago Künnap published one text by Kai Donner recorded as Chaya dialect (Künnap 1992). After comparing this text to the texts by Grigorovskij, we can distinguish several features of Donner's Chaya dialect (worth mentioning that Helimski (1983: 15-16) briefly discusses the following features):

1) Peculiarities of diphthong usage: For example, șierna (Künnap 1992: 141), whereas the same verb in Grigorovskij's texts is recorded as се́ргу 'войти/enter' (for example, sentences no. 65, 464, 478 in Grigorovskij 1879a). It is noteworthy, that in the same text by Donner this lexeme also appears without diphthong: Mãtte sêrlut 'entered the house' (Künnap 1992: 142). We cannot exclude free variation. And it is still unclear whether the ${ }^{\mathrm{i}}$ in Donner's transcription denotes palatalization or both diphthongization and palatalization. Judging by the four lexemes above, Grigorovskij paid attention to the diphthongs as well. Despite that fact, he did not record any diphthong in this lexeme. 
Another example of diphthong usage in Donner's text: i $\hat{\partial} \hat{r}-\partial \eta$ drink-3sG.SUB (Künnap 1992: 142), whereas Grigorovskij recorded it as biopbl-, blp- 'to feast' (GH 1647, Xelimskij and Grigorovskij 2007: 220), юе́ренди 'drunk' (cf. SkWb 276).

2) Assimilation of consonants: For instance, $n d \sim d d, m b \sim b b$. This type of assimilation is also recorded in the far south $\mathrm{Ob}$ vernaculars of Sondorovo, Taizakovo (cf. Filippova 2011). This type of assimilation is considered to be one of the late phenomena which appeared at the turn of the 19th and the 20th century (Filippova 2011, Janurik 1984). This

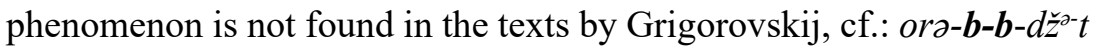
strength-VBLZ-DUR-TR-3SG.OB (Künnap 1992: 141) órym-b-at growPSTN-3PL (Sentence 213 and Grigorovskij 1879a); $a m-n \boldsymbol{e}-\boldsymbol{b}-\boldsymbol{b}$ - $\boldsymbol{a}$ eat-NEG. PTCL.VBLZ-PSTN-3SG.SUB (Künnap 1992: 142) $\sim m$-b-an eat-PSTN-3sG. SUB (Sentence 29 and Grigorovskij 1879a).

The preliminary analysis shows that Donner's Chaya text and Grigorovskij's Chaya texts belong to the Southern Selkup dialectal group and at the same time have a number of features, which do not permit them to be considered as belonging strictly to one and the same vernacular. Nevertheless, it is necessary to continue the investigation to confirm or disprove this premise.

According to the analysis in Part 4 of this article, the isoglosses highlighted by Helimski (2004) help to make a clear distinction among the Northern, Southern and Central dialectal groups. However, we need additional isoglosses to make distinctions within each of these groups, in particular, within the Southern one. Most probably, the further strategy of dialectal identification of Grigorovskij's texts should be based on the investigation of the following features:

3) The vowels in the first syllable: the dialects within the Southern dialectal group could be classified by this feature, as shown in (Katz 1979: 104, Glushkov et al. 2004). The availability and quality of diphthongs could play a significant role in this investigation.

4) So called long consonants are considered to be a distinctive feature of the Ket dialect (the Southern dialectal group) (Xelimskij 2004: 73). The "long" consonant is most often placed at the beginning of a syllable and follows a short vowel or a sonant (Xelimskij 2004: 73). This phenomenon is not found in the texts by Grigorovskij. 


\section{Conclusion}

The first Selkup books published in the 19th century by Grigorovskij can be regarded as consistently recorded material. The biographical information proves that Grigorovskij had quite a decent education in humanities, enough to work with the rank of collegiate secretary in the West Siberian Department of the Imperial Geographic Society. It is noteworthy that he gained great credibility among the Selkups who actively took part in his translations. The historical documents confirm that the Southern Selkups at the end of the 19th century understood and accepted these texts. It should be stressed that Russian borrowings are indeed deeply rooted into the speech of Grigorovskij's informants, and the translator very accurately recorded them with that level of Russian interference into the Selkup language, which was common to the Selkup speakers living in the region of the Chaya in the 1870s.

The main obstacle when defining the dialect of Grigorovsky's texts is that there are no clearly described borders and distinctions among the dialects within the South Selkup dialectal group. However, it can be clearly seen that Grigorovskij's texts, recorded in Jurty Kostenkiny at the lower course of the Chaya river, belong to one of the Southern dialects. Nevertheless, they contain a number of consistent distinctions, which may indicate the attribution to an insufficiently described Southern dialect (Chaya, Upper-Ob, Lower Ket or another). Furthermore, the list of isoglosses by Helimski shows that Grigorovskij's lexemes have common features with the Ket, Upper Ob, Sondrovo, Chaya and Bajdona vernaculars/dialects. As it can be seen from the paradigms in Tables 1 and 2, the inflections from Grigorovskij's texts are very similar to the Middle $\mathrm{Ob}$, Upper $\mathrm{Ob}$ and Ket ones, but still have distinctive features. At the same time the Chaya texts by Grigorovskij recorded in 1870s cannot be called the same vernacular as the Chaya texts recorded by Donner at the beginning of the 20th century due to the differences in the diphthong usage, assimilation of consonants and vowels in the first syllable. The features mentioned above contain potential for the distinction among the South Selkup dialects. And this article analyses and presents the most distinctive isoglosses which can help to make a clearer distinction between the South Selkup dialects, which does not yet exist. 


\author{
Address \\ Nadezhda Fedotova \\ 50061 Russia, Kemerovo \\ Ul. Serebryany bor, 13-42 \\ E-mail: nadia.krass@gmail.com
}

\begin{abstract}
Abbreviations
1, 2, 3 - 1st, 2nd, 3rd person, ABL - ablative case, ACC - accusative case, CAR - caritive case, DEST - destinative case, DU dual number, DUR - durative aktionsart, GEN - genitive case, INST - instrumental case, LAT - lative case, LOC - locative case, NEG.PTCL - negative particle, .ob - objective conjugation, PL - plural number, PROL - prolative case, PSTN - narrative past tense, SG - singular number, sub - subjective conjugation, TR - transitive, TRSL - translative case, vBLZ - verbalizer
\end{abstract}

Dialects:

Bajdona OO - Donner Bajdona village Upper Ob vernacular (1911); KeM - Middle Ket dialect (Metaškina, Maksimkin Jar, Urljukovo); KeMMJ - Middle Ket dialect, Maksimkin Jar vernacular; $\mathrm{KeO}$ - Upper Ket dialect, Makovskoe vernacular; $\mathrm{KeOL}$ - Upper Ket, Laskova vernacular; KeUC - Ket dialect (from Donner Čajaheft 1913.04); KeUM Ket dialect (from Donner 1912, Muljoškina); KM - Middle Ket dialect in general; KUS - Lower Ket dialect, Sangaúrov vernacular; Nar. Narym dialect; Sondorovo OOS - Sondrovo vernacular (Donner 1911); Sondorovo OSA - Sondrovo vernacular (Alatalo 1923); Taizakovo OOT - Taizakovo vernacular (Donner 1911); Taz. - Taz dialect.

\title{
References
}

Alatalo, Jarmo (2004) Sölkupisches Wörterbuch aus Aufzeichnungen von Kai Donner, U.T. Sirelius und Jarmo Alatalo. Helsinki: SUS.

Bekker, Erika G., Larisa A. Alitkina, Valentina V. Bykonja, and Irina A. Il'jašenko (1995) Morfologija sel'kupskogo jazyka. Južnye dialekty. Čast' I. Tomsk.

Bekker, Erika G., Valentina V. Bykonja, Aleksandra A. Kim, and Šimon Kuper (1994) Posobie po sel'kupskomu jazyku. Tomsk. 
Bykonya, Valentina V., Nadežda G. Kuznecova, and Natal'ja P. Maksimova (2005) Sel'kupsko-russkij dialektnyj slovar'. Tomsk.

Castrén, Matthias A. (1854) Grammatik der samojedischen Sprachen. St.-Petersburg.

Čsepregi, Márta (1976) “Ki volt Grigorovszkij?”. Néprajz és Nyelvtudomány 19-20, 217-223.

Filippova, Tat'jana M. (2011) “Osobennosti verxneobskogo govora južnyx selkupov (Tajzakovo-Starosondrovskaja gruppa)”. Vestnik NGU (Serija: Istorija, Filologija, Tom 10. Vyp. 2: Filologija), 81-87.

Gluškov, Sergej V. (2001) "Mesto čainskogo dialekta v rjadu drugix dialektnyx podrazdelenij sel'kupskogo jazyka". Samodijycy. Materialy IV Sibirskogo simpoziuma "Kulturnoe nasledie narodov Zapadnoj Sibiri" (10-12 dekabrja 2001), 197-198.

Glushkov, Sergej V., Natalija Tučkova, and Alexandra Baidak (2004) "The Kenga Subdialect of the Selkup Language". Finnisch-Ugrische Mitteilungen 26/27, 49-56.

Grigorovskij, Nikolaj P. (1879a) Svjaščennaja istorija na ostjako-samoedskom jazyke. Kazan.

Grigorovskij, Nikolaj P. (1879b) Ob"jasnyenie prazdnikov Svjatoy Cerkvi. Kazan.

Grigorovskij, Nikolaj P. (1879c) Azbuka Sjussogoj gulani. Kazan.

Grigorovskij, Nikolaj P. (1879d) Molitvy i o serdečnoj molitve k Bogu. Kazan.

Hajdú, Peter (1973) Azbuka sjussogojy gulani. (Studia Uralo-Altaica, 2.) Szeged.

Helimski, Eugene (1983) The Language of the first Selkup books. Szeged.

Janurik, Tamás (1984) "Über die Konsonantenphoneme der sölkupischen Mundarten". In Péter Hajdú and László Honti, eds. Bibliotheca Uralica. Studien zur phonologischen Beschreibung uralischer Sprachen, 51-67. (Bibliotheca Uralica, 7.) Budapest.

Katz, Hartmut (1988) Selkupica IV. Die Märchen in Grigorovskis Azbuka. Neuried.

Katz, Hartmut (1979) Selkupische Quellen. Ein Lesebuch. Wien.

Kazakevič, Ol'ga A. and Elena M. Budjanskaya (2010) Dialektologičeskij slovar' sel'kupskogo jazyka (severnoe narečie). Ekaterinburg.

Kiseleva, E. G. and S. I. Nikiforova (1969) "K voprosu o sisteme glasnyx karelinskogo govora ketskogo dialekta sel'kupskogo jazyka”. Materialy mežvuzovskoj konferencii (11-13 maya 1969) "Proisxoždenie aborigenov Sibiri i ix jazykov", 79-81.

Kolležskij sekretar'. Available online at <http://wordweb.ru/en_ru_byt/06_04.htm>. Accessed on 05.04.2018.

Korobejnikova, Irina A. (2009) Slovar' narymskogo dialekta sel'kupskogo yazyka. $<$ http://lingvodoc.ispras.ru/dictionary/334/3/perspective/334/4/view >. Accessed on 21.04.2018.

Kuz'mina, Ariadna I. (1974) Grammatika sel'kupskogo jazyka. Čast' I: Sel'kupy i ix jazyk. Učebnoe posobie. Novosibirsk.

Kuznecova, Nadežda G. (1995) Grammatičeskie kategorii južnosel'kupskogo glagola. Tomsk.

Künnap, Ago (1979) "Russkie leksičeskie zaimstvovanija v južnosamodijskix jazykax (19-20 vv.)". Fenno-Ugristica 6, 51-66. 
Künnap, Ago (1992) “Selkupin Iidjä-Satu Tšajan murteella vuodelta 1913”. FennoUgristica 18, 141-147.

Meletij, arxim. (1876) “O predpolagaemyx perevodax Svjaščennogo Pisaniya na ostjackij jazyk”. Pribavlenija k Irkutskim jeparxial'nym vedomostyam (January 17) 3, 27-33.

Pozdeeva, Galina P. (2013) “Dialekty sel'kupskogo jazyka: verifikacija obščeprinjatyx klassifikatsij i novij vzgljad na dialektnoe členenie". Uralo-altajskie issledovaniya $1,8,20-33$.

Prokof'ev, Georgij N. (1937) “Selkupskij (ostjako-samoedskij) jazyk.” Jazyki i pismennost'narodov Severa. Čast' I: Jazyki i pisjmennost'samoedskix i finno-ugorskix narodov, 91-124. Moskva-Leningrad.

Pusztay, János and Šimon Kuper (1993) Sel'kupski razgovornik (narymskij dialekt). Szombathely.

Rassamaxin, Jurij Kuz'mič (2000) “Kommentarij k očerkam N.P. Grigorovskogo "Krestjanskaja svad'ba", "Mnenija i predanija o mamonte u narymskix inorodcev"”. Zemlja kolpaševskaja: sbornik naučno-popularnyx očerkov, 267-274.

"Selkupskij jazyk". Jazyki narodov Sibiri, naxodjaščiesja pod ugrozoy isčeznovenija. Available online at $<\mathrm{http}$ ///ingsib.iea.ras.ru/ru/languages/selkup.shtml $>$. Accessed on 16.02.2018.

Tučkova, Natal'ja A. (2014) Sel'kupskaya ojkumena. Obžitoe prostranstvo sel'kupov južnyx i central'nyx dialektnyx grupp. Tomsk.

Vserossijskaja perepis' naselenija 2010. Tom 4. Nacionaljnyj sostav i vladenie jazikami, graždanstvo. Available online at $<$ http://www.gks.ru/free_doc/new_site/ perepis2010/croc/Documents/Vol4/pub-04-01.pdf>. Accessed on 15.04.2018.

Xelimskij, Evgenij (2004) “K istoričeskoj dialektologii sel'kupskogo jazyka”. Komparativistika, uralistika: Lekcii i stat'i, 68-79. Moskva.

Xelimskij, Evgenij (2007) Severnosel'kupskij slovar' (sel'kupsko-russkij i russko-sel'kupskij). Hamburg.

Xelimskij, Evgenij and Nikolaj P. Grigorovskij (2007) Južnoselkupskij slovar' N.P. Grigorovskogo. Hamburg.

\section{Kokkuvõte. Nadežda Fedotova: Esimeste N. P. Grigorovski sölkupi raama-} tute taust ja teaduslik potentsiaal. Siinse artikli eesmärk on välja selgitada, miks on siiani lahtine 19. sajandil Nikolaj Grigorovski poolt kogutud sölkupi tekstide murdeline määratlus. Ka annab artikkel esmased tulemused isoglosside piiride kohta lõuna-sölkupi murdegrupis ja pakub strateegiaid sellele probleemile lähenemiseks. Uurimisteema arendamiseks on esmalt esimesed 19. sajandi sölkupi raamatud (1879) viidud digitaalse tekstikorpuse kujule. Tekstianalüüs on välja toonud keelelised tunnused, mida ühest küljest kinnitavad ka 20. sajandi sölkupi materjalid (seda verbi pöördeliste ja noomenite käändeliste paradigmade põhjal ning põhiliste sölkupi isoglosside põhjal, mille on välja toonud Helimski 2004). Teisalt aga näitab analüüs, et murdelised 
nähtused on ebapiisavalt kirjeldatud. Artikkel sisaldab ka erinevates allikates esinevatest fragmentidest kokku kombineeritud varianti Grigorovski bibliograafiast.

Märksõnad: lõuna-sölkupi murded, Grigorovski biograafia, murdeline määratlus, noomenite käänamine, verbide pööramine, isoglossid

\begin{abstract}
Аннотация. Надежда Федотова: История и перспектива исследования первых книг на селькупском языке Н. П. Григоровского. Целью статьи является выявление причин, в связи с которыми проблема определения диалектной принадлежности первых селькупских текстов, собранных в XIX веке Николаем Григоровским, остается открытой. В статье даны предварительные варианты изоглосс, позволяющие отличить южную диалектную группу селькупского языка от других диалектных групп. С тем чтобы углубить исследование, первые селькупские книги XIX века (1879) были оцифрованы и преобразованы в аннотированный корпус текстов. Анализ на основе данного корпуса позволил обнаружить языковые явления, которые, с одной стороны, точно совпадают с селькупскими материалами, зафиксированными в XX веке (на примере парадигм спряжения селькупских глаголов и склонения существительных, а также с основными изоглоссами, предложенными Хелимским [Xelimskij 2004]). С другой стороны, они демонстрируют диалектные явления, которые недостаточно подробно описаны в литературе. В статье также предложена наиболее полная версия биографии Григоровского как компиляция из различных источников.
\end{abstract}

Ключевые слова: южные селькупские диалекты, биография Григоровского, диалектная принадлежность, склонение существительных, спряжение глаголов, изоглоссы 